\title{
MULTIPLE ANTIBIOTIC RESISTANCE IN POULTRY ISOLATES OF CAMPYLOBACTER
}

\section{Tavuk Kökenli Campylobacter'lerde çoklu antibiyotik dirençliliği}

Summary: Out of 206 poultry isolates of thermophilic campylobacters (137 C.jejuni, 69. C. coli), 100, 43.6, 18.4, 3.9, 6.3, 6.8, 3.4 and $8.3 \%$ were resistant to penicillin, ampicillin, tetracyline, erythromycin, chloramphenicol, streptomycin, gentamicin and kanamvcin, respectivelv. All strains were sensitive to enrofloxacin and ciprofloxacin. A total of 15 multiresistance patterns were determined in $17.5 \%$ of isolates. Multiresistance was more frequent among $C$. coli strains (26\%), than C. jejuni (13.8\%).

Özet: Tavuklardan izole edilen 206 termofolik Campylobacter susunda (137 C. jejuni, 69 C. coli) penisilin, ampisilin, tetraksiklin, eritromisin, kloramfenikol, streptomisin, gentamisin ve kanamasine karsi, strasıla \%100, 43.6, $18.4,3.9,6.3,6.8,3.4$ ve 8.3 orantunda dirençlilik saptand. Incelenen tüm suşlar enrofloksasin ve siprofloksasine duvarl bulundu. Suslarm \%17.5'inde toplam 15 çoklu dirençlilik tablosu belirlendi. Çoklu dirençlilik, C. coli suşlarında (\%26), C. jejuni (\%13.8) suslarma göre daha yüksek oranda görüldii.

\section{Introduction}

Campylobacter enteritis is the commonest form of the infective diarrhea in many countries of the world. Campylobacter spp. are more frequently isolated from stool specimens from patients with diarrhea than enterohemorrhagic Escherichia coli. Salmonella and Shigella together $(8,15)$. Campylobacter infection is mainly a foodborne disease in which contaminated chicken meat play a particularly important role ( 1 , 12 ). Indeed, poultry represents the most important reservoir for these organisms: campylobacters have been isolated from $97.5 \%$ of broiler carcasses ready for marketing in Turkey (19). Campylobacters were isolated from $10.6 \%$ of diarrheic children and found to be the most common enteric pathogen in Turkey (8).

Treatment with an antibiotic shown to be effective in vitro can be of value in that it eradicates the campylobacters in the intestine. Although, campylobacter species are generally sensitive to many antimicrobial agents compared with other Gram negative enteric pathogens (11), emergence of resistance development is being reported by several authors. In particular, resistance to erythromycin, tetracycline and quinolones has been shown to increase and geographical differences in the frequency of resistance to these agents have been indicated (6, $10,16)$. Multiple antibiotic resistance in campylobacters has been rarely reported $(13,14,18)$. A significant difference between the antibiotic susceptibilities of campylobacters obtained from humans and chickens (16). Since, antibiotics used in human Campylobacter infections are also used in poultry as therapeutic agents or feed additives, the resistance patterns of poultry strains carry importance for therapeutic regiments in human medicine. In some countries, an association of increased resistance rates with increased use of quinolones in the poultry industry has been demonstrated (6).

This study was conducted to determine the antimicrobial susceptibilities and multiple resistance patterns of poultry isolates of campylobacters in Turkey.

\section{Materials and Methods}

A total of 206 Campylobacter strains ( 137 C. jejuni and 69 C. Coli) isolated from intesti- 
nes or carcasses of broiler chickens between 1992 and 1993 were studied. Chickens were trom 25 different flocks. All strains had been isolated by direct plating onto Blaser-Wang selective medium (Oxoid) or Preston selective medium (Oxoid) and incubating under microaerobic atmosphere $\left(5 \% \mathrm{O}_{2} .10 \% \mathrm{CO}_{2}, 85 \% \mathrm{~N}_{2}\right)$ at $37^{\circ} \mathrm{C}$.

Antimicroabial susceptibilities of campylobacters were determined by disc diffusion method (2). Disc diffusion tests were performed on Mueller Hinton agar (Oxoid). Campylobacters were grown in Mueller-Hinton broth (Oxoid) under microaerobic atmosphere at $37^{\circ} \mathrm{C}$ for 24 h. Approaximately $10^{8} \mathrm{cfu}$ in $0.1 \mathrm{ml}$ were inoculated on each plate. After antibiotic discs were placed, plates were kept at room temperature for $30 \mathrm{~min}$. and then incubated under microaerobic atmosphere at $37^{\circ} \mathrm{C}$ for $36 \mathrm{~h}$. The zone of inhibition was measured and taken as resistant or sensitive. The following discs (Oxoid) of antibiotics were used: penicillin (10 iu), ampicillin $\left(10^{\circ} \mathrm{g}\right)$, tetracylcline $\left(30^{\circ} \mathrm{g}\right)$, erythromycin $(15 \cdot \mathrm{g})$, chloramphenicol (30 $\cdot \mathrm{g})$, enrofloxacin (5 $\mathrm{g}$; Difco), ciprofloxacin $(5 \cdot \mathrm{g})$. streptomycin $(10 \cdot \mathrm{g})$, gentamicin $(10$ g) and kanamycin $(30 \cdot \mathrm{g})$.

\section{Results}

The susceptibilities of the isolates to the antimicrobial agents studied are shown in Table 1. All $C$. jejuni and $C$. coli strains were resistant to penicillin and sensitive to fluoroquinolones, including enrofloxacin and ciprofloxacin. The susceptibilities of campylobacters to ampicillin, tetracycline, erythromycin, chloramphenicol, streptomycin, gentamicin and kanamycin were $43.6,18.4,3.9,6.3,6.8,3.4$ and $8.3 \%$, respectively. Resistance to ampicillin, tetracyline, erythromycin, chloramphenicol. streptomycin, gentamicin and kanamycin was detected in 46.7. $15.3,2.1,4.3,5.8,3.6$ and $3.6 \%$ of $C$. jejuni isolates and $37.6,24.6,7.2,10.1,8.6,2.8$ and $17.3 \%$ of $C$. coli isolates.

Table 1. Antimicrobial susceptibilitics of 206 poultry isolatcs of Campylobacter to 10 antimicrobial agents.

\begin{tabular}{|c|c|c|c|c|c|c|}
\hline \multicolumn{3}{|c|}{ Antimicrobial agent } & \multicolumn{4}{|c|}{ Resistance ( $\%$ ) } \\
\hline & \multicolumn{2}{|c|}{ C. jejuni (n: 137) } & \multicolumn{3}{|c|}{ C. Coli (n: 69) } & $\begin{array}{c}\text { Total } \\
\text { (n: } 206)\end{array}$ \\
\hline Penicillin & 137 & $1100.0)$ & 69 & $(100.0)$ & 206 & $(100.0)$ \\
\hline Ampicillin & 64 & $(46,7)$ & 26 & $(37.6)$ & 90 & $(43.6)$ \\
\hline Enrol]oxacin & 0 & & () & & () & \\
\hline Ciprofloxacin & 0 & & () & & 0 & \\
\hline Telracycline & 21 & $(15.3)$ & 17 & $(24.6)$ & $3 x$ & $(18.4) !$ \\
\hline Erylluromucin & 3 & $(2.1)$ & 5 & $(7.2)$ & $s$ & 13.91 \\
\hline Chloramphenical & 6 & $(4.3)$ & 7 & $(10.1)$ & 1.3 & $(6.3)$ \\
\hline Sireptomycin & 8 & $(5.8)$ & 6 & $(8.6)$ & 14 & $(0.8)$ \\
\hline Gentamicin & 5 & $(3.6)$ & 2 & $(2 . x)$ & 7 & $(3.4)$ \\
\hline Kanamycin & 5 & $(3.6)$ & 12 & $(17.3)$ & 17 & $(8.3) \mathrm{i}$ \\
\hline
\end{tabular}

A total of 15 multiresistance patterns were determined (Table 2). Since all isolates were resistant to penicillin, this agent was not included in the evaluation of multiple resistance patterns. The numbers of strains which were resistant to two to six antibiotics were $12,11,9,3$ and 1 . respectively. Multiresistance was detected in $13.8 \%$ of $C$. jejuni and $26 \%$ of $C$. coli. One $C$. jeiuni and three $C$. coli isolates were the most resistant strains, being resistant to six and five antibiotics, respectively. Out of $82.3 \%$ of kanamycin resistant strains were also resistant to tetracycline. Of 25 poultry flocks investigated, $12(48 \%)$ were found to harbour multiple resistant strains. Each of the multiple resistance patterns was generally found in the different flocks.

\section{Discussion}

The resistance of Campylobacter strains to 10 antimicrobial agents was generally low, except penicillin and ampicillin. All strains studied were resistant to penicillin and $43.6 \%$ to ampicillin. The results of this study, in general agrement with those obtained by others $(3,10$, 16), showed that B-Lactam antibiotics were not very active against $C$. jejuni and $C$. coli. $B$. lactam resistance is associated with B-lactamase production (17), and most of the human isolates have been shown to produce this enzyme (4).

All isolates examined in this study were sensitive to enrofloxacin and ciprofloxacin. Human strains of campylobacters have been reported to be fully sensitive to quinolones in Turkey (7). A rapid increase in resistance to quinolones after the introduction of this group of antibiotics into poultry industry has been reported (6). Introduction of quinolones into poultry practice after 1991 in Turkey may explain why resistance to ciprofloxacin and enrofloxacin could not be detected in this study.

The frequencies of tetracycline and erythromycin resistance among isolates were $18.4 \%$ and $3.9 \%$, respectively. Extensive use of tetracylines in poultry industry as a feed additive and rare use of erythromycin in poultry medicine in Turkey may be associated with relatively high and low levels of resistance to these antibiotics. In other countries, resistance to tetracycline up to $55 \%$, and resistance to erythromycin up to $17 \%$ has been reported (14.16). Although, most erythromycin resistant strains have been proved to be $C$. coli in previous reports $(3.14)$, three erythromycin resistant strains of $C$ jejumi were found in this study.

In the study, resistance of campylobacters to kanamycin, streptomycin and gentamicin was found $8.3,6.8$ and $3.4 \%$ respectively. De- 
rable 2. The patterns of multiple antibiotic resistance among poultry isolates of $C$. jejuni and $C$. coli.

\begin{tabular}{|c|c|c|c|c|c|c|c|c|c|c|}
\hline \multirow[b]{2}{*}{ Pattem No. } & \multirow[b]{2}{*}{ Amp } & \multicolumn{6}{|c|}{ Antimicrobial ag̣ent* } & \multicolumn{3}{|c|}{ Number of strains } \\
\hline & & $\mathrm{Tet}$ & Ery & Kan & Sur & $\mathrm{Chl}$ & Gen & C. jejuni & C. coli & Total \\
\hline 1 & $\mathbf{R}$ & $\mathrm{R}$ & - & - & - & - & - & 6 & 2 & 8 \\
\hline 2 & - & $\mathbf{R}$ & - & - & $\mathrm{R}$ & - & - & 2 & - & 2 \\
\hline 3 &.. & $\mathrm{R}$ & - & - & - & $\mathrm{R}$ & - & - & 1 & 1 \\
\hline 4 & - & - & $\mathrm{R}$ & - & $\mathrm{R}$ & - & - & 1 & - & 1 \\
\hline 5 & $\mathrm{R}$ & $\mathrm{R}$ & . & $\mathrm{R}$ & . & - & - & - & 4 & 4 \\
\hline 6 & $\mathrm{R}$ & $\ddot{R}$ & - & - & - & - & $\mathrm{R}$ & 2 & - & 2 \\
\hline 7 & . & $\mathrm{R}$ & . & $\mathrm{R}$ & $\mathrm{R}$ & . & 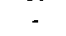 & 2 & 1 & 3 \\
\hline 8 & - & - & $\mathrm{R}$ & $\mathrm{R}$ & $\mathrm{R}$ & - & & 1 & - & 1 \\
\hline 9 & $\mathrm{R}$ & - & - & - & - & $\mathrm{R}$ & $\mathbf{R}$ & - & 2 & 1 \\
\hline 10 & $\mathrm{R}$ & $\mathrm{R}$ & - & - & - & $\mathrm{R}$ & $\mathrm{R}$ & 3 & - & 3 \\
\hline 11 & $\mathrm{R}$ & $\mathrm{R}$ & - & - & $\mathrm{R}$ & $\mathrm{R}$ & - & - & 1 & 1 \\
\hline 12 & R & $R$ & - & $\mathrm{R}$ & $\mathrm{R}$ & - & - & 1 & 2 & 3 \\
\hline 13 & - & R & $\mathbf{R}$ & R & $\mathrm{R}$ & - & - & - & 2 & 2 \\
\hline 14 & $\mathrm{R}$ & $\mathrm{R}$ & $\mathrm{R}$ & $\mathrm{R}$ & - & $\mathrm{R}$ & - & - & 3 & 3 \\
\hline 15 & $\mathrm{R}$ & $\mathrm{R}$ & $\mathrm{R}$ & $\mathrm{R}$ & $\mathbf{R}$ & $\mathrm{R}$ & - & 1 & - & 1 \\
\hline
\end{tabular}

* Antimicrobial agents: Amp, ampicillin, Tet, tetracycline: Ery. erythromycin; Kan, Kanamycin. Str. streptomycitr: Chl. chloramphenicol: Gen, gentamicin.

R: Resistant.

tection of resistance to these antibiotics was interesting since none of these have been used in poultry practice in Turkey. Human isolates of C. jejuni and $C$. coli have also been reported to be sensitive to these antimicrobials in Turkey (9). In general, C. coli was more resistant than $C$. jejuni to antimicrobial agents studied except ampicillin and gentamicin.

In a study conducted in Turkey in 1987 (5). it has been reported that, all C. jejuni isolates from poultry were sensitive to antibiotics used in this study, except penicillin and ampicillin. In the same report, different degrees of resistance to all antibiotics have been detected in ruminant isolates and it has been suggested that ruminant strains were more resistint than poultry strains. When comparing the r'sults of this study, a marked development of resistance in poultry strains of campylobacters is ipparent and it may be suggested that this may be caused by the transmission of campylobacters among different animal species.

A total of 15 multiresistance patterns were determined in this study. Since all isolates were resistant to penicillin, this agent was iot included in the evaluation of multiple resistance patterns. The high number of resistance patterns may be associated with the distribution of isolates studied into 25 different flocks. Of 25 poultry flocks investigated, 12 (48\%) were found to harbour multiple resistant strains. Each of the multiple resistance patterns was generally found in the different flocks.

Multiresistance was more frequent among C. Coli strains (26\%) than C. jejuni $(13.8 \%)$.
One $C$. jejuni and three $C$. coli strains had the widest ranges of resistance, being resistant to six and five antibiotics, respectively. Sagara et al. (14) have also noted the high prevalence of multiple resistance in $C$. coli. Most of the resistance patterns reported by Pinto-Alphandary. Mabilat \& Courvalin (13) were also detected in this study (multiple resistance patterns no. 2, 4. $5,7,12,15$ in Table 2). No strong association was found between antibiotics except that $82.3 \%$ of kanamycin-resistant strains were also resistant to tetracycline. In this study, it was also determined that kanamycin, erythromycin, streptomycin or gentamicin resistance was always seen in multiple resistant strains.

In conclusion, although resistance of poultry isolates of campylobacters to antibiotics is not as high as comparing with other countries. the development of resistance is in progress.

\section{References}

1. Altekruse, S.F., Hunt, J.M., Tollefson, L.K. \& Madden, J.M. (1994). Food and animal sources of human Campylobacter jejuni infection. $3 \mathrm{Am}$ Vet Med Assoc, 204, 57-61.

2. Bauer, A.W., Kirby, W.M., Sherris, J.C. \& Turck. M. (1966). Antibiotic susceptibilitv testing bv a standardized single disk method. Am J Clin Pathol. 45, 493-497.

3. Bradbury, W.C. \& Munroe, D.L.G. (1985). Occurrence of plasmids and antibionic resistance antong (amprlobacter joimi and $C$. coli isolated from heallin and diarrheic ani. nuals. I Clin Microbiol. 22. 339-346.

4. Diker, K.S., Akan, M., Hascelik, (;. \& Fmekdas. G. (1991). Br-Lacramase production in human and animal isolates. Canpvlobacter jejmi in Turkev. I Antinicrob Chemollucr, 27, 693-694 
5. Diker, K.S., Yardımcı, H., Aydın, N. \& Arda, M. (1987). The coniparison of in vitro antimicrobial susceptibi. lity of Campylobacter jejuni from avian and bovine-ovine origin. Ankara Üniv. Vet. Fak. Derg., 34, 549-554.

6. Endt $z$, H.P., Ruijs, G.J, van Klingeren, B., Jansen, W.H., van der Reyden, T. \& Mouton. P. (1991). Quinolone resistance in campylobacter isolated from man and poultry following the introduction of fluoroquinolones in veterinary medicine. J Antimicrob Chemother, 27, 199-208.

7. Gür, D., Hasçelik, G., Akyön, Y., Akalın, H.E. \& Diker, S. (1989) Campylobacter jejuni ve C. colinin quinolone grubu antibiyotiklere in vitro duyarliliklart. Mikrobiyol Bul, 23, 185-189.

8. Hasçelik, G., Akan, Ö.A., Diker, S. \& Baykal, M. (1991). Camplobacter and enterohemorrhagic Escherichio coli (EHEC) associated gastroenteritis in Turkish children. J Diarrh Dis Res, 9, 315-317.

9. Hascelik, G., Akyön, Y., Berkman, F., Diker, S. \& Oran, O. (1990). Campylobacter jejuni ve Campylobacter coli susslarmm in vitro antibiyotik duyarlilikların!n karsillastırılmast. Çocuk Sağ] Hast. Derg., 33, 15-19.

10. Iariviere, L.A., Gaudreau, C.L. \& Turgeon, F.F. (1986). Susceptibility of clinical isolates of Canipylobacter jejuni to iwentv-five antinicrobial agents. $J$ Antimicrob Chemother, 18, 681-685.

11. McNulty, C.A.M. (1987). The treatment of campvlobacter infections in man. J Antimicrub Chemother, 19, 281-284.
12. Park, R.W.A., Griffiths, P.L. \& Moreno, G.S. (1991). Sources and survival of campwlobacters: relcvance to emeritis and food industn. I App Bacteriol, 70, s.97-s.106.

13. Pinto-Alphandary, H., Mabilat, C. \& Courvalin, P. (1990). Eniergence of aminoglvcoside genes aadA and aadE in the genus Campylobacter. Antimicrob Ag Chemother, 34. 1294-1296.

14. Sagara, H., Mochizuki, A., Okamura, N. \& Nakaya, R. (1987). Antinicrobial resistance of Campylobacter jejuni and Campylobacter coli with special reference to plasmid profiles of Japanase clinical isolates. Antimicrob Ag Chemother, 31, 713-719.

15. Skirrow, M.B. (1987). A demographic survey of campylobacter, salmonella and shigella infections in England. A public health laborotory service survev. Epidemiol Infect, 99, 647-657.

16. Svedhem, A., Kaijser, B. \& Sjögren, E. (1981). Antimicrobial susceptibility of Canipylobacter jejuni isolated from humans with diarrhoea and from heallhy chickens. J Antimicrob Chemother, 7, 301-305.

17. Taylor, D.E. \& Courvalin, P. (1988). Mechanisms of antibiotic resistance in Campylobacter species. Antimicrob Ag Chemother, 32, 1107-1112.

18. Winstanley, T.G., Rice, P.S. \& Spencer, R.C. (1993). Multiple antibiotic resistance in a strain of Campvlo bacter jejumi acquired in Jordan. J Antimicrob Chemuther, 31. 178-179.

19. Yıldı, A. \& Diker, K.S. (1992). Camipviobacter conta mination in chicken carcasses. Turk J Vet Anin Sci, 16, 433439 . 